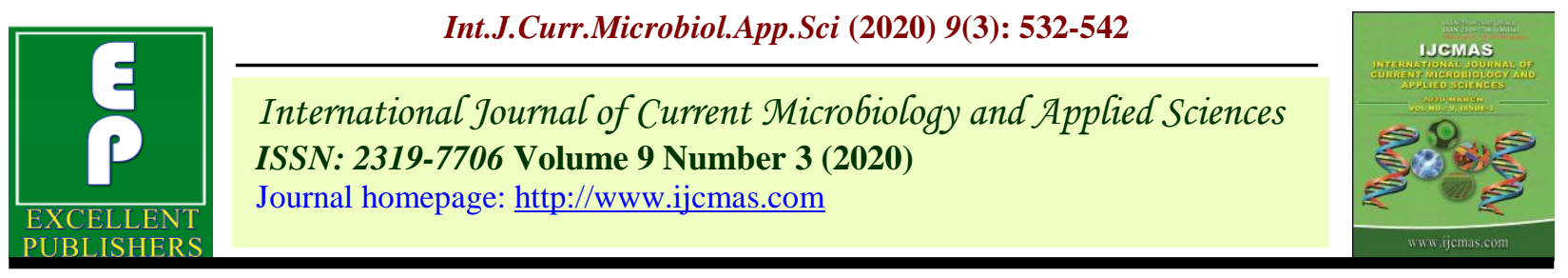

Original Research Article

https://doi.org/10.20546/ijcmas.2020.903.062

\title{
Effect of Foliar Application of Micronutrient on Quality and Shelf Life in Table Grapes under Tropical Conditions of India
}

\author{
J. M. Khilari ${ }^{1}$, S. D. Ramteke ${ }^{2}$, Shared Bhagwat ${ }^{1 *}$, J. N. Kalbhor ${ }^{1}$, \\ T. S. Shelake ${ }^{1}$ and M. A. Bhange ${ }^{2}$
}

${ }^{I} R \&$ D Unit, Maharashtra Grape Growers Association Manjari Farm,Pune - 412307, India

${ }^{2}$ ICAR-National Research Centre for Grapes, Pune - 412307, India

*Corresponding author

\begin{abstract}
A B S T R A C T
Keywords

Grapes, yield, quality, visual quality, shelf life and nutrients.

Article Info

Accepted: 05 February 2020 Available Online: 10 March 2020

This investigation aimed to study the effect of foliar applications of Silicon, Boron and Calcium- ETDA alone or combinations at different berry development stages to determine their effects on growth parameters, shelf life, yield and quality in table grapes under tropical conditions of India. The experiment was carried out at The experimental trial was carried out onClone 2A Seedless grapes grafted on Dogridge rootstock in the Maharashtra Rajya Draksh Bagaitdar Sangh, vineyard for the year (2016-2017). Pune $\left(18.32{ }^{\circ} \mathrm{N}\right.$ and $\left.73.51^{\circ} \mathrm{E}\right)$ has tropical wet and dry climate with an average temperature ranging between 20 to $28{ }^{\circ} \mathrm{C}$.The result obtained proved that all parameters such as vegetative growth, total chlorophyll content, leaf area $\mathrm{m}^{2}$,bunch weight, berries weight, berry diameters, berry size, TSS acidity were improved while compared with untreated control. The $\mathrm{Si}, \mathrm{Ca}-$ EDTA and B treated vines recorded minimum fresh weight loss $\%$ and longer shelf life compared with alone and untreated control. The Si, Ca - EDTA + B treated leaves rachis and petiole had the highest $\mathrm{Si}, \mathrm{Ca}-\mathrm{EDTA}$ and $\mathrm{B}$ content uptake. Therefore, Si, Ca-EDTA + B foliar sprays increased and retained yield, quality, berry firmness, visual quality, and nutrient content, prolonged shelf life was noted in the study.
\end{abstract}

\section{Introduction}

Grape (Vitis vinifera L.) is a non-climacteric fruit subject to serious quality loss after harvest mainly due to water loss which cause stem browning and sensitivity to microbial decay. Rachis browning is the most important physiological disorder of table grapes poststorage while, the primary pathological spoilage problem is decay caused by Botrytis cinerea (Lichter, 2016). Usually, a green rachis is an indicator of freshness and hence 
unmaturated rachis can be a cause of consumer rejection and fruit waste. Maturation of grape berries is accompanied by many morphological and physiological process influenced by internal and external factors such as Nutrients, growth regulators, light, temperature and plant water status(Azuma, 2018; Gao-Takai et al., 2017; Sugiura et al., 2018). Nutrients are important that helps to plant growth, deficient plants exhibit various visible symptoms and disorders.

A number of studies have been conducted on the physiological function of boron (O'Neill et al., 2001) and the mechanisms of boron transport (Tanaka et al., 2008; Nakagawa et al., 2007). Exogenous application of boron was shown to alleviate the occurrence of browning injuries in pears during controlled atmosphere storage (Xuan et al., 2005).

Studies show that boron can influence the cell wall and plasma membrane cell wall interface, metabolism, reproductive growth and development, and root elongation and shoot growth of a growing plant structure (Marschner, 2012). It is known that boron treatment can augment and enhance the quality of tomato and cucumber plants during growth stages (Ekinci et al., 2015).

Rachis dehydration (browning) is a substantial determinant for post-harvest quality, because it extends the shelf life by modifying firmness of the fruit cell-wall. Silicon or $\mathrm{Si}+\mathrm{B}$ have the ability once applied to modify this result in the berry structure.

In this study, we investigated the effects of micronutrients ( $\mathrm{Si}$, Boron and $\mathrm{Ca}-\mathrm{ETDA}$ ) alone or combinations application at the berry development stages to determine their effects on growth parameters, shelf life, yield and quality in table grapes under tropical conditions of India.

\section{Materials and Methods}

The experimental trial was carried out on Clone 2A Seedless grapes grafted on Dogridge rootstock in the Maharashtra Rajya Draksh Bagaitdar Sangh, vineyard for the year (2016-2017). Pune (18.32 ${ }^{\circ} \mathrm{N}$ and $73.51^{\circ} \mathrm{E}$ ) has tropical wet and dry climate with an average temperature ranging between 20 to $28{ }^{\circ} \mathrm{C}$. Six-year-old vines of Clone 2Agrafted onto dogridge rootstock were selected for the study.

The vines were planted in N-S direction with spacing of $2.66 \mathrm{mtr}$ between the rows and $1.33 \mathrm{mtr}$ between the vines. The vines were trained to Y- trellises with double cordon placed in horizontal orientation. The application of nutrients was done as shown in Table 1. The nutrients were mixed in water and sprayed with a knapsack sprayer at different berry developmental stages such as pre-flowering, 2-3 mm, 6-8 $\mathrm{mm}$ berry size. The experiment was laid out in randomized block design with seven treatments with three replications. Five vines were selected under each replication to record the observations. Recommended dose of fertilizer as well as crop protection measures were adopted as good agricultural practices.

To study the effect of micronutrient treatments on growth, yield, quality and postharvest, clusters under each treatment were harvested on the same date. The shoot length and shoot diameter were measured at 120 days after fruit pruning. At harvest, average clusters weight, 100-berry weight and yield per vine was recorded. Hundred berry samples were randomly selected from each replicate and processed in a blender and strained through two layers of muslin cloth. Soluble solids concentration was determined from the juice using a digital refractometer (model ERMA of Japan). 
The uniformly ripened grape bunches were harvested in replicate from each treatment. The harvested bunches ( $5 \mathrm{~kg} /$ treatment) were placed in cardboard boxes and kept in cold storage $\left(0^{\circ} \mathrm{C}\right)$ for 30 days as per the guidelines of international standard. After removing bunches from cold storage, observations were recorded daily up to15days (at the same time) for physiological loss in weight (PLW) or shelf life. The initial weight of fresh fruit was recorded and subsequently the weights were taken. The physiological loss in weight was estimated as given below and expressed in percent.

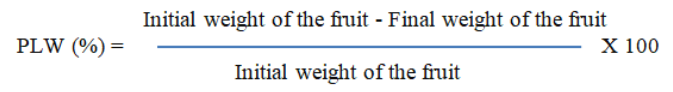

The data were presented as an average for all the different characters studied. The experiment was conducted in randomized block design consisting of seven treatments as different micronutrient combination. All calculations were performed using the GLM procedure of SAS System software, version 9.3.

\section{Results and Discussion}

Influence of micronutrients on vegetative growth parameters of grape vines

The observations recorded on various vegetative parameters were presented in Table 2. Significant differences were recorded for all the parameters studied. The highest $(133.33 \mathrm{~cm})$ shoot length was obtained with application of Si + Ca -EDTA + Boron @ 1 $\mathrm{ml} / 1+0.5 \mathrm{~g} / \mathrm{Lit}+0.05 \%$ it was followed $\mathrm{Si}+$ Boron@ $1 \mathrm{ml} / \mathrm{l}+0.05$ \%by $(124.00 \mathrm{~cm})$, while it was least with control treatment $(68.67 \mathrm{~cm})$. Similar trends were obtained for shoot diameters, leaf area $\mathrm{m}^{2}$ and no. of berries per vine in this investigation. All these parameters increased with increase concentration of applied nutrients alone or combinations. Similar report was reported by Mahran (2005) the reported that increase in vegetative parameters with the application of Sida compound.

Recently, Khan et al., (2012) observed that foliar application of a mixture of amino acids and seaweed (Ascophyllum nodosum) significantly increased the leaf size of 'Perlette' grapevine. Similarly, Kalidindi et al., (2002), reported that Increase in number of fruit bunch per plant was maximum for B followed by $\mathrm{N}+\mathrm{B}+\mathrm{Zn}$, with the latter showing an intermediate response between $\mathrm{B}$ and $\mathrm{N}$. Increase in number of bunch per plant could be related to a favorable synthesis and in situ concentration of different hormones particularly, cytokinin and auxin. However, the actual mechanism governing differential response of nutrients is obscure.

In this investigation total chlorophyll contents were significantly increased over untreated control treatments. The highest (1.35) chlorophyll contents was recorded with $\mathrm{Si}+$ Ca-EDTA + Boron@ @ $1 \mathrm{ml} / 1+0.5 \mathrm{~g} / \mathrm{Lit}+$ $0.05 \%$ while it was least with control treatment (1.01). These proved that vines treated with high rate of nutrients with alone or combination has been increases the total chlorophyll content in the leaves. Similar results were obtained by Abdel-Salam et al., (2016) they reported that the treatments with salicylic acid increases total chlorophyll contents in grapevines.

They also proved that vines treated with high rate of micronutrients only or in combination with Salicylic acid have been got the highest rate of chlorophyll content in the leaves. Similarly, Hayat et al., 2010 reported that Salicylic acid increased leaf area, and subsequently rate of photosynthesis, total carbohydrates and photosynthetic pigments thereby; the bio-productivity of crops was increased. 
Influence of micronutrients on yield parameters and quality parameters of grape vine

Significant differences were recorded on yield and quality parameters presented in Table 3. The highest bunch weight $(276.00 \mathrm{~g})$ was recorded with the application of $\mathrm{Si}+\mathrm{Ca}-$ EDTA + Boron@ $1 \mathrm{ml} / \mathrm{l}+0.5 \mathrm{~g} / \mathrm{Lit}+0.05 \%$ followed by $(272.67 \mathrm{~g}) \mathrm{Si}+$ Boron @ $1 \mathrm{ml} / \mathrm{l}+$ $0.05 \%$ while it was least (203.33) with untreated control. Similar trends were obtained for 100 berry weight, berry length and berry diameter, total soluble solids, and acidity in this investigation.

The results obtained in this study might be due to the application of nutrient with alone or combination. These results were found in harmony with the work of (Hayat et al., 2005 and Marzouk and Kassem 2011). Foliar application of micronutrients $(\mathrm{Fe}, \mathrm{Zn}, \mathrm{Mn}$ and $\mathrm{Br}$ ) had been associated with improved number of clusters, an average of cluster's weight, juice content and the quality of vines (Beede et al., 2005, Malakouti, 2007 and Akbar et al., 2013).

Increasing in bunch weight and berry weight which sprayed with $\mathrm{Si}, \mathrm{Ca}$-EDTA and Boron could be attributed to increase berry set, a number of berry in cluster and cell size or cell number resulting hence competition of photosynthetic substance between berries on a cluster (Ebadi et al., 2001). In general, to get the best price of table grapes in domestic and export markets, there are some characteristics for the cluster of grapes such as large berries, compactness cluster, firmness berries and sweetness.

Foliar treatments with $\mathrm{Si}, \mathrm{Ca}-$ EDTA and Boron gave positive effects on these parameters might account for enhanced physical properties of cluster and berries. $\mathrm{Si}$, $\mathrm{Ca}$-EDTA and Boron conserves berry firmness by affecting activities of prime cell wall degrading enzymes such as xylanase, cellulose, polygalacturonase and promotes cell division and cell enlargement (Hayat et al., 2005).

Data recorded on quality parameters $\mathrm{Viz}$. TSS and acidity were found non-significant. TSS and acidity values that increased by the $\mathrm{Si}, \mathrm{Ca}$ -EDTA and Boron might account to the function of $\mathrm{Si}$ which delayed ripening. Compared results between micronutrients treatments and treatments which included of SA proved that the treatments which contained a higher amount of micronutrients, achieved lower acidity (Moustafa et al., 1986, Elena et al., 1998).

\section{Influence of micronutrients on fresh weight losses in grape vine}

The results on fresh weight loss (\%) in grapes packaged kept with $5^{\circ} \mathrm{C}$ and room temperature is shown in Fig.1. The results obtained for fresh weight loss $\%$ during storage of 15 days was minimum with the vine sprayed with $\mathrm{Si}+\mathrm{Ca}-\mathrm{EDTA}+$ Boron @ $1 \mathrm{ml} / \mathrm{l}+0.5 \mathrm{~g} / \mathrm{Lit}+0.05 \%$ followed by $\mathrm{Si}+$ $\mathrm{Ca}$-EDTA while maximum weight loss with untreated control.

Similarly, trends were obtained for bunches stored at room temperature in this investigation. Moreover, at $5^{\circ} \mathrm{C}$, the stored grapes showed less fresh weight loss than at room temperature. The results in this investigation might be due to the application of $\mathrm{Si}$ and Boron alone or combination which reduce the respiration of grape berry.

The study confirms the findings of Mohammad et al., 2018. Who reported that $\mathrm{Si}$ $+\mathrm{B}$ treated tomato fruits showed the lowest fresh weight loss during storage. This might be due to because of fruits moisture loss from respiration during stored tomato fruits fresh 
weight loss rate increases when weighed and reviewed. Anonymous (Singh et al., 2007), reported that the pre-harvest foliar sprays in strawberries studied did not show any differences in fresh weight loss. But our results for $\mathrm{Si}$ alone or $\mathrm{Si}+\mathrm{B}$ alone or combination showed significantly different in grapes in this investigation.

\section{Influence of micronutrients on visual quality in grape vine}

The data recorded on visual quality in grapes stored at $5^{\circ} \mathrm{C}$ and room temperature was presented in Fig 2. Grapes market price usually depends on visually high quality of the fruits.

Therefore, good visual quality fruits are preferable to the sellers, buyers and consumers in all buying markets. In this investigation significant differences were recorded within the treatments.

Results obtained in this investigation showed the $\mathrm{Si}+\mathrm{Ca}-\mathrm{EDTA}+$ Boron treated fruits at $5^{\circ} \mathrm{C}$ and room temperature storage had the best quality with increased concentration. The marketable, good visual grapes quality or shelf life $(\geq 3)$ was maintained for 10 days (control), 15 days ( $\mathrm{Si}$ alone or $\mathrm{Si}+\mathrm{Ca}-$ EDTA) 20 days ( $\mathrm{Si}+\mathrm{Ca}-\mathrm{EDTA}+$ Boron) at $5^{\circ} \mathrm{C}$ based on an observation scale fig 2 .

Moreover, at Room temperature storage grape shelf life was 6 days (control), 8 days ( $\mathrm{Si}$ alone or $\mathrm{Si}+\mathrm{Ca}-\mathrm{EDTA})$ and 9 days $(\mathrm{Si}+\mathrm{Ca}$ -EDTA + Boron) Fig. 2.

The $\mathrm{Si}+\mathrm{Ca}-\mathrm{EDTA}+$ Boronfoliar sprayed vines retainedvisual quality, improved the shelf life, and maintained the fruit freshness might be due to suppressing respiration and reducing internal breakdown. The silicon alone or combination treatment also resulted in a better visual quality over the control as indicated in this investigation.

Similarly, Ouzounidou et al., 2016 who reported that $\mathrm{Si}$ reduced deterioration of cucumber by maintaining membrane integrity. $B$ reduced the susceptibility of nectarine fruit rots caused by brown rot (Thomidis et al., 2017).

This study confirms the grapes visual quality improved their shelf life and maintained freshness for a longer period of time. The $\mathrm{Si}$ $+\mathrm{Ca}-\mathrm{EDTA}+$ Boron foliar spray resulted in longer shelf life in grapes at both $5^{\circ} \mathrm{C}$ and room temperature by maintaining freshness.

\section{Leaf, Rachis and petiolSilicon + Calcium - EDTA + Boron) content analysis}

Data recorded on nutrient analysis from leaf, petiole and rachis were presented in Table 4, 5 and 6 . The results indicate the $\mathrm{Si}+\mathrm{Ca}-$ EDTA + Boron were found higher compared to untreated control in this study. The results in obtained in this investigation might be due to greater assimilation of $\mathrm{Si}+\mathrm{Ca}-\mathrm{EDTA}+$ Boron in the leaves, rachis and petiole.

As the grapevines accumulated higher $\mathrm{Si}+\mathrm{Ca}$ -EDTA + Boron contents, the cell wall thickness, fruit firmness and shelf life increased Fig 1 and 2.

Similarly, The B treatment increased the B content in cucumbers and in tomatoes (Kaya et al., 2011; Ekinci et al., 2015). On the other hand, (Sarangthem and Singh 2003) found that, the foliar application of Salicylic acid enhanced the N, P, K, Cu, Fe, Zn, Na and Mn and increased the level of proteins and nitrate reductive activity. 
Table.1 Treatment Details

\begin{tabular}{|l|l|}
\hline Treatment & Dose \\
\hline T1. $\mathbf{S i}$ & $\mathbf{1}$ g/lit \\
\hline T2. Ca-EDTA & $0.5 \mathrm{~g} / \mathrm{Lit}$ \\
\hline T3.- Boron & $0.05 \%$ \\
\hline T4.Si+ Ca - EDTA & $0.5 \mathrm{~g} / \mathrm{Lit}+0.05 \%$ \\
\hline T5.Si + Boron & $0.5 \mathrm{~g} / \mathrm{Lit}+0.05 \%+0.5 \mathrm{~g} / \mathrm{Lit}$. \\
\hline T6. Si + Ca - EDTA+ Boron & $0.5 \mathrm{~g} / \mathrm{Lit}+0.05 \%+0.5 \mathrm{~g} / \mathrm{Lit}+0.125 \mathrm{~g} / \mathrm{Lit}$ \\
\hline T7. Control & No Spray \\
\hline
\end{tabular}

Table.2 Effect of microelements on vegetative parameters at 90 days after pruning

\begin{tabular}{|c|c|c|c|c|c|}
\hline Treatments & $\begin{array}{l}\text { Shoot } \\
\text { length } \\
(\mathbf{c m})\end{array}$ & $\begin{array}{c}\text { Shoot } \\
\text { diameter } \\
(\mathbf{m m})\end{array}$ & $\begin{array}{l}\text { No. of bunches } \\
\text { per vines }\end{array}$ & $\begin{array}{c}\text { Leaf area } \\
\left(\mathbf{m}^{2}\right)\end{array}$ & $\begin{array}{c}\text { Total } \\
\text { Chlorophyl } \\
\text { l } \\
(\mathrm{mg} / \mathrm{g})\end{array}$ \\
\hline T1.Si @ $1 \mathrm{ml} / \mathbf{l}$ & 80.00 & 7.60 & 32.67 & 157.67 & 1.07 \\
\hline $\begin{array}{l}\text { T2. Ca-EDTA @ } 0.5 \\
\text { g/Lit }\end{array}$ & 94.67 & 8.00 & 35.00 & 168.67 & 1.11 \\
\hline T3.- Boron@ @ $0.05 \%$ & 102.67 & 8.43 & 38.33 & 174.00 & 1.15 \\
\hline $\begin{array}{l}\text { T4.Si + Ca-EDTA@ } 1 \\
\mathrm{ml} / \mathrm{l}+0.5 \mathrm{~g} / \mathrm{Lit}\end{array}$ & 113.33 & 8.93 & 42.33 & 180.67 & 1.19 \\
\hline $\begin{array}{l}\text { T5. Si+ Boron @ } 1 \\
\mathrm{ml} / \mathrm{l}+0.05 \%\end{array}$ & 124.00 & 9.10 & 44.00 & 184.00 & 1.25 \\
\hline $\begin{array}{l}\text { T6. Si + Ca -EDTA + } \\
\text { Boron @ } 1 \mathrm{ml} / \mathrm{l}+0.5 \\
\text { g/Lit + 0.05\% }\end{array}$ & 133.33 & 9.27 & 47.67 & 191.67 & 1.35 \\
\hline T7. Control & 68.67 & 7.46 & 29.33 & 137.67 & 1.01 \\
\hline CD @ 5\% & 1.47 & 0.14 & 0.88 & 0.69 & 0.76 \\
\hline c.v. $\%$ & 8.24 & 2.76 & 8.04 & 2.99 & 3.34 \\
\hline Significance & $*$ & $* *$ & * & $*$ & $*$ \\
\hline
\end{tabular}


Table.3 Effect of microelements on yield and quality parameters in grapes

\begin{tabular}{|c|c|c|c|c|c|c|c|}
\hline Treatments & $\begin{array}{l}\text { Avg. bunch } \\
\text { weight (g) }\end{array}$ & $\begin{array}{l}\text { No. of berries } \\
\text { per bunch }\end{array}$ & $\begin{array}{l}100 \text { berry } \\
\text { weight }(\mathrm{g})\end{array}$ & $\begin{array}{l}\text { Berry diameter } \\
(\mathbf{m m})\end{array}$ & $\begin{array}{c}\text { Berry } \\
\text { length }(\mathbf{m m})\end{array}$ & TSS $\left({ }^{\circ} \mathbf{B}\right)$ & $\begin{array}{l}\text { Acidity } \\
(\%)\end{array}$ \\
\hline T1.Si @1 ml/l & 227.33 & 111.67 & 187.33 & 16.43 & 16.00 & 23.17 & 4.42 \\
\hline T2.Ca-EDTA@0.5 g/Lit & 236.00 & 113.33 & 195.00 & 16.53 & 16.33 & 22.67 & 4.63 \\
\hline T3.- Boron@0.05\% & 256.67 & 116.67 & 197.00 & 16.97 & 16.53 & 22.00 & 4.80 \\
\hline $\begin{array}{l}\text { T4.Si + Ca-EDTA@ } 1 \text { ml/l + } 0.5 \\
\text { g/Lit }\end{array}$ & 263.33 & 126.67 & 206.33 & 17.97 & 17.50 & 21.00 & 4.93 \\
\hline T5. Si + Boron@ 1 ml/l + $0.05 \%$ & 272.67 & 131.00 & 210.67 & 18.17 & 18.00 & 20.67 & 5.10 \\
\hline $\begin{array}{l}\text { T6. Si + Ca-EDTA + Boron @ } 1 \\
\text { ml/l + 0.5 g/Lit + } 0.05 \%\end{array}$ & 276.00 & 140.00 & 217.33 & 18.33 & 18.50 & 20.00 & 5.43 \\
\hline T7. Control & 203.33 & 102.67 & 150.67 & 15.33 & 15.00 & 23.33 & 4.42 \\
\hline CD@ $9 \%$ & 1.06 & 1.07 & 0.89 & 0.14 & 0.21 & 0.28 & 0.19 \\
\hline c.v. \% & 3.79 & 5.49 & 3.62 & 1.99 & 2.92 & 3.38 & 4.46 \\
\hline Significance & $*$ & NS & $*$ & $*$ & $*$ & NS & NS \\
\hline
\end{tabular}

Table.4 Effect of microelements on nutrient status in leaf at 90 days after pruning

\begin{tabular}{|c|c|c|c|c|c|c|c|c|c|c|c|c|c|}
\hline Treatments & $\begin{array}{c}\mathbf{N} \\
(\mathbf{\%})\end{array}$ & $\begin{array}{c}\mathbf{N H}_{\mathbf{4}}-\mathbf{N} \\
(\mathbf{p p m})\end{array}$ & $\begin{array}{c}\mathbf{P} \\
(\mathbf{\%})\end{array}$ & $\begin{array}{c}\mathbf{K} \\
(\mathbf{\%})\end{array}$ & $\begin{array}{c}\mathbf{C a} \\
(\mathbf{\%})\end{array}$ & $\begin{array}{c}\mathbf{M g} \\
(\mathbf{\%})\end{array}$ & $\begin{array}{c}\mathbf{S} \\
(\mathbf{\%})\end{array}$ & $\begin{array}{c}\mathbf{F e} \\
(\mathbf{p p m})\end{array}$ & $\begin{array}{c}\mathbf{M n} \\
(\mathbf{p p m})\end{array}$ & $\begin{array}{c}\mathbf{Z n} \\
(\mathbf{p p m})\end{array}$ & $\begin{array}{c}\mathbf{C u} \\
(\mathbf{p p m})\end{array}$ & $\begin{array}{c}\mathbf{N a} \\
(\mathbf{\%})\end{array}$ & $\begin{array}{c}\text { Boron } \\
\mathbf{p p m}\end{array}$ \\
\hline $\mathbf{1}$ & 2.85 & 86.00 & 0.23 & 1.10 & 1.82 & 0.62 & 0.30 & 533 & 388 & 164 & 31.00 & 0.65 & 53 \\
\hline $\mathbf{2}$ & 3.25 & 91.00 & 0.25 & 1.15 & 1.84 & 0.64 & 0.27 & 455 & 422 & 129 & 15.00 & 0.65 & 57 \\
\hline $\mathbf{3}$ & 4.25 & 91.00 & 0.24 & 1.15 & 1.86 & 0.65 & 0.29 & 337 & 340 & 128 & 15.00 & 0.75 & 59 \\
\hline $\mathbf{4}$ & 3.92 & 177.00 & 0.25 & 1.05 & 1.74 & 0.46 & 0.37 & 436 & 366 & 132 & 13.00 & 0.6 & 55 \\
\hline $\mathbf{5}$ & 3.7 & 118.00 & 0.27 & 1.34 & 1.72 & 0.64 & 0.40 & 456 & 338 & 139 & 16.00 & 0.7 & 63 \\
\hline $\mathbf{6}$ & 2.97 & 195.04 & 0.28 & 1.55 & 2.09 & 0.65 & 0.47 & 397 & 387 & 130 & 8.00 & 0.7 & 69 \\
\hline $\mathbf{7}$ & 3.42 & 380.00 & 0.22 & 1.05 & 1.55 & 0.75 & 0.26 & 454 & 388 & 126 & 7.00 & 0.75 & 45 \\
\hline
\end{tabular}


Table.5 Effect of microelements on nutrient status in petiole at 90 days after pruning

\begin{tabular}{|c|c|c|c|c|c|c|c|c|c|c|c|c|c|c|}
\hline Treatments & $\begin{array}{c}\mathbf{N H}_{\mathbf{4}}-\mathbf{N} \\
(\mathbf{p p m})\end{array}$ & $\begin{array}{c}\mathbf{N} \\
(\mathbf{\%})\end{array}$ & $\begin{array}{c}\mathbf{N H}_{\mathbf{4}}^{-} \\
\mathbf{N}\end{array}$ & $\begin{array}{c}\mathbf{P} \\
(\mathbf{\%})\end{array}$ & $\begin{array}{c}\mathbf{K} \\
(\mathbf{\%})\end{array}$ & $\begin{array}{c}\mathbf{C a} \\
(\mathbf{\%})\end{array}$ & $\begin{array}{c}\mathbf{M g} \\
(\mathbf{\%})\end{array}$ & $\begin{array}{c}\mathbf{S} \\
(\boldsymbol{\%})\end{array}$ & $\begin{array}{c}\mathbf{F e} \\
(\mathbf{p p m})\end{array}$ & $\begin{array}{c}\mathbf{M n} \\
(\mathbf{p p m})\end{array}$ & $\begin{array}{c}\mathbf{Z n} \\
(\mathbf{p p m})\end{array}$ & $\begin{array}{c}\mathbf{C u} \\
(\mathbf{p p m})\end{array}$ & $\begin{array}{c}\mathbf{N a} \\
(\mathbf{\%})\end{array}$ & $\begin{array}{c}\text { Boron } \\
\mathbf{p p m}\end{array}$ \\
\hline $\mathbf{1}$ & 900.00 & 1.23 & 353 & 0.34 & 1.65 & 1.55 & 0.81 & 0.11 & 228 & 343 & 80 & 3 & 0.7 & 60 \\
\hline $\mathbf{2}$ & 1100.00 & 1.06 & 384 & 0.37 & 1.72 & 1.97 & 0.78 & 0.11 & 177 & 326 & 71 & 3 & 0.75 & 59 \\
\hline $\mathbf{3}$ & 950.00 & 1.12 & 353 & 0.36 & 1.45 & 1.4 & 0.82 & 0.11 & 146 & 338 & 70 & 3 & 0.7 & 65 \\
\hline $\mathbf{4}$ & 1200.00 & 1.20 & 376 & 0.34 & 1.4 & 1.82 & 0.84 & 0.11 & 141 & 319 & 80 & 21 & 0.75 & 57 \\
\hline $\mathbf{5}$ & 1450.00 & 1.06 & 338 & 0.31 & 1.35 & 1.26 & 0.84 & 0.1 & 130 & 323 & 74 & 3 & 0.75 & 72 \\
\hline $\mathbf{6}$ & 700.00 & 1.33 & 285 & 0.39 & 1.35 & 2.00 & 0.84 & 0.1 & 160 & 317 & 76 & 3 & 0.65 & 80 \\
\hline $\mathbf{7}$ & 1800.00 & 1.02 & 406 & 0.44 & 1.5 & 1.59 & 0.86 & 0.1 & 165 & 329 & 75 & 8 & 0.62 & 55 \\
\hline
\end{tabular}

Table.6 Effect of microelements on nutrient status in rachis at 90 days after pruning

\begin{tabular}{|c|c|c|c|c|c|c|c|c|c|c|c|}
\hline Treatments & $\begin{array}{l}\mathbf{N} \\
\%\end{array}$ & $\begin{array}{l}\mathbf{P} \\
\%\end{array}$ & $\begin{array}{l}\mathrm{K} \\
\%\end{array}$ & $\begin{array}{l}\mathrm{Ca} \\
\%\end{array}$ & $\underset{\%}{\mathrm{Mg}}$ & $\begin{array}{l}S \\
\%\end{array}$ & $\begin{array}{c}\mathrm{Fe} \\
\text { ppm }\end{array}$ & $\begin{array}{l}\text { Mn } \\
\text { ppm }\end{array}$ & $\begin{array}{c}\text { Zn } \\
\text { ppm }\end{array}$ & $\begin{array}{c}\mathrm{Cu} \\
\text { ppm }\end{array}$ & $\begin{array}{l}\mathrm{Na} \\
\%\end{array}$ \\
\hline 1 & 1.21 & 0.24 & 1.55 & 0.38 & 0.18 & 0.10 & 195 & 44.00 & 23.00 & 2.00 & 0.30 \\
\hline 2 & 1.10 & 0.25 & 1.55 & 0.42 & 0.23 & 0.10 & 173 & 36.00 & 17.00 & 3.00 & 0.20 \\
\hline 3 & 1.05 & 0.22 & 1.75 & 0.37 & 0.21 & 0.10 & 174 & 37.00 & 17.00 & 3.00 & 0.25 \\
\hline 4 & 1.08 & 0.24 & 1.35 & 0.42 & 0.21 & 0.10 & 212 & 38.00 & 16.00 & 4.00 & 0.2 \\
\hline 5 & 1.00 & 0.25 & 1.55 & 0.34 & 0.22 & 0.1 & 175 & 35.00 & 16.00 & 3.00 & 0.35 \\
\hline 6 & 1.53 & 0.25 & 1.3 & 0.63 & 0.21 & 0.12 & 192 & 40.00 & 18.00 & 3.00 & 0.30 \\
\hline 7 & 1.00 & 0.22 & 1.65 & 0.31 & 0.2 & 0.12 & 137 & 35.00 & 16.00 & 3.00 & 0.30 \\
\hline
\end{tabular}




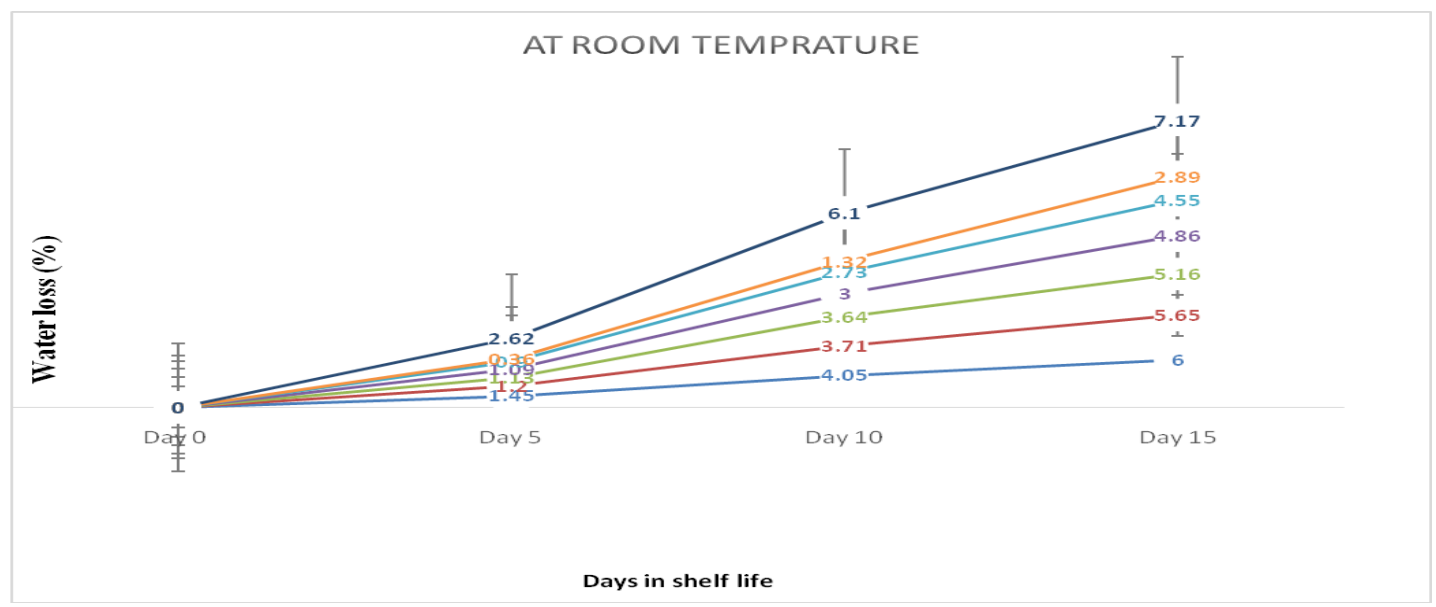

Fig.1a Fresh weight loss \% (at room temperature)

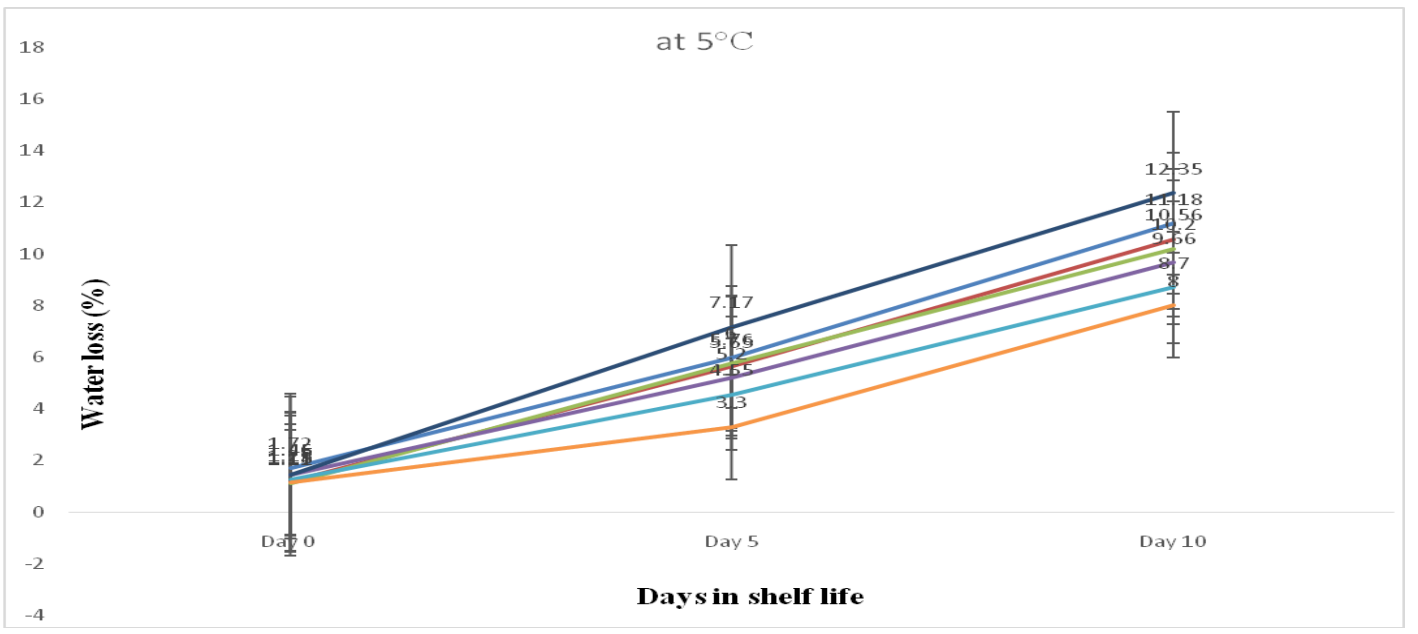

Fig.1b Fresh weight loss $\%$ (at $5^{\circ} \mathrm{C}$ temperature)

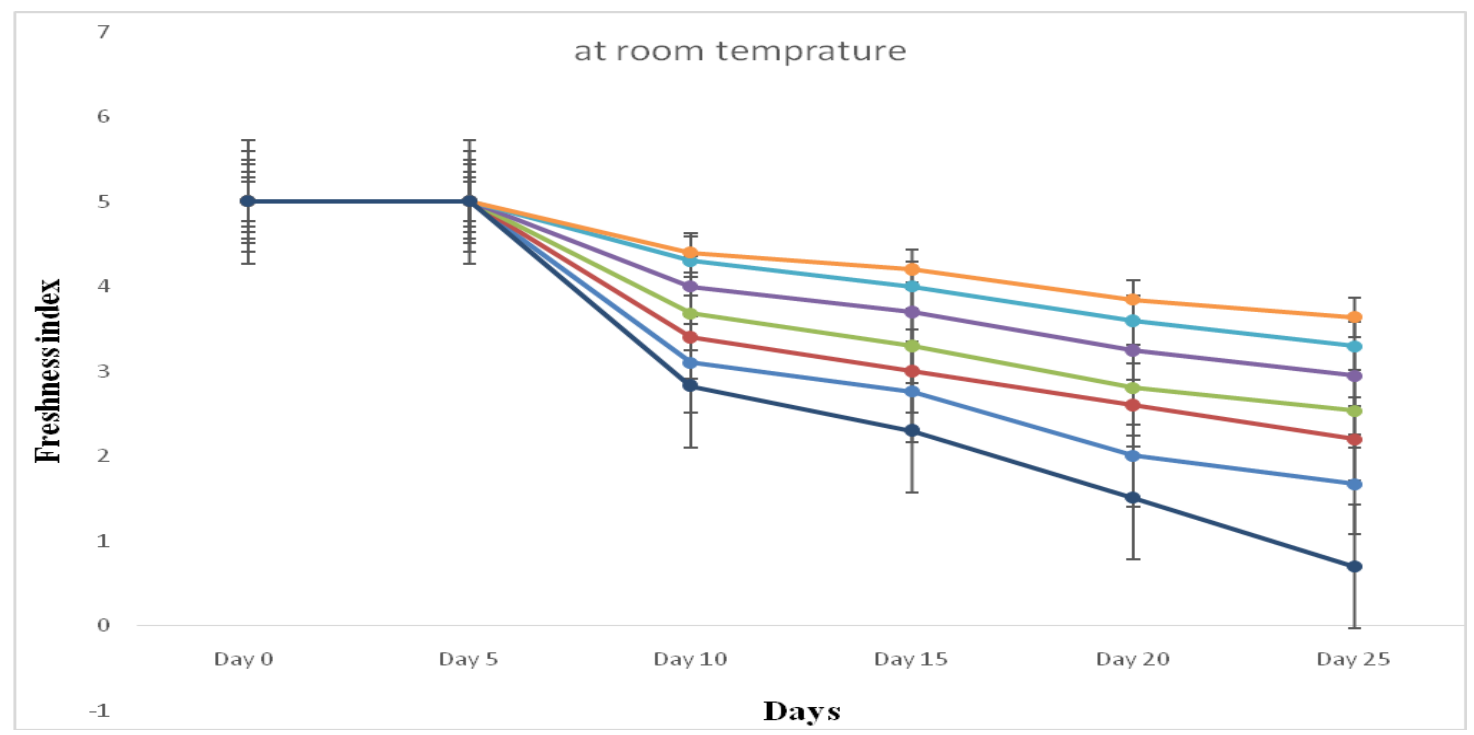

Fig.2a Effect of microelements on visual quality of grapes at room temperature 
The effects of foliar spraying of silicon ( $\mathrm{Si}$ ), Calcium (Ca) -EDTA and Boron alone or combination were investigated to confirm the quality and shelf life of grapes. The application of $\mathrm{Si}+\mathrm{Ca}-\mathrm{EDTA}+\mathrm{B}$ treatment showed increased yield quality and shelf life in grapes might be due to lower respiration, less ethylene production, increased firmness, increased cell-wall compactness, and accumulated maximum $\mathrm{Si}+\mathrm{Ca}$-EDTA + Boron content compared with alone treatment or control in grapes. The application with combination of $\mathrm{Si}+\mathrm{Ca}-\mathrm{EDTA}+$ Btreatment also had a prolonged shelf life in this study.

\section{References}

Akbar, S., M. Vahid, T.P. Ahmad, A. Abdolreza, 2013. Effect of $\mathrm{Zn}, \mathrm{Cu}$ and Fe foliar application on fruit set and some quality and quantity characteristics of pistachio trees South Western Journal of Horticulture, Biology and Environment, 4(1): 19-34.

Azuma, A. 2018. Genetic and environmental impacts on the biosynthesis of anthocyanins in grapes. Hort. J. 87: 117.

Beede, R.H., P.H. Brown, C. Kallsen, S.A. Weinbaum, 2005. Diagnosing and correcting nutrient deficiencies. In: L. Ferguson (ed), Pistachio production manual. 4th edition. Division of Agriculture and Natural Resources. University of California: Oakland. 147157.

Ebadi, A., D. Atashkar, M. Babalar, 2001. Effect of boron on pollination and fertilization in seedless grapevine cvs White Seedless and Askari. Iranian Journal Agriculture Sciences, 32(2): 457-465.

Ekinci M., Esring A., Dursun A., Yildirim E., TuranM., Karaman M. R., Arjumend T. 2015. Growth, yield, and calcium and boron uptake of tomato (Lycopersicon esculentum L.) and cucumber (Cucumis sativus L.) as affected by calcium and boron humate application in greenhouse conditions. Turkish Journal Agriculture and Forestry, 39: 613-632. https://doi.org/10.3906/tar-1406-59.

Elena, K., C. Andary, A. Rbonneaua, A. Deloire, 1998. Salicylic acid treatment of grape berries retards ripening. Vitis, 37(3): 143-144.

Gao-Takai, M., A. Katayama-Ikegami, S. Nakano, K. Matsuda and H. Motosugi. 2017. Vegetative growth and fruit quality of 'Ruby Roman' grapevines grafted on two species of rootstock and their tetraploids. Hort. J. 86: 171-182.

Hayat, Q., S. Hayat, M. Irfan, A. Ahmad, 2010. Effect of exogenous salicylic acid under changing environment: A review. Environmental and Experimental Botany, 68: 14-25.

Hayat, S., Q. Fariduddin, B. Ali, A. Ahmad, 2005. Effect of salicylic acid on growth and enzyme activities of wheat seedlings. Acta. Agron. Hung., 53: 433 437.

Lichter, A. 2016. Rachis browning in tablegrapes. Aust. J. Grape Wine Res. 2: 161-168.

Maha M. Abdel-Salam (2016). Effect of Foliar Application of Salicylic Acid and Micronutrients on the Berries Quality of "Bez El Naka" Local Grape Cultivar Middle East Journal of Applied Sciences. 06, 178-188

Malakouti, M.J., 2007. Zinc is a neglected element in the life cycle of plants: A review. Middle Eastern and Russian Journal of Plant Science and Biotechnology, 1: 1-12.

Marschner H. 2012. Mineral nutrition of higher plants. London, UK, p. 347-364.

Marzouk, H.A., H.A. Kassem, 2011. Improving yield, quality and shelf life of Thompson seedless grapevine by preharvest foliar applications.SciHortic, 
130: 425-430.

Mohammad Zahirul ISLAM, Mahmuda Akter MELE, Ki-Young CHOI, Ho-Min KANG (2018). The effect of silicon and boron foliar application on the quality and shelf life of cherry tomatoes Zemdirbyste-Agriculture, vol. 105, No. 2 , p. 159-164. DOI $10.13080 / \mathrm{z}-$ a.2018.105.020.

Moustafa, A., A.S.A. Elshazly, A.M. Eissa, M.A. Zahran, 1986. Effect of foliar applications of chelated $\mathrm{Fe}, \mathrm{Zn}$ and $\mathrm{Mn}$ on leaf mineral content, yield and fruit quality of Roumi Red grape-vines. Annals of Agricultural Sciences, 31: 623- 635.

Nakagawa, Y., Hanaoka, H., Kobayashi, M., Miyoshi, K., Miwa, K., Fujiwara, T., 2007. Celltype specificity of the expression of Os BOR1, a rice efflux boron transporter gene, is regulated in response to boron availability for efficient boron uptake and xylem loading. Plant Cell 19, 2624-2635.

O'Neill, M., Eberhard, S., Albersheim, P., Darvill, A.G., 2001. Requirement of borate crosslinking of cell wall rhamnogalacturonan II for Arabidopsis growth. Science 294, 846-849.

Ouzounidou G., Giannakoula A., Ilias I., Zamanidis P. 2016. Alleviation of drought and salinity stresses on growth, physiology, biochemistry and quality of two CucumissativusL. by Si application. Brazilian Journal of Botany, 39 (2): 531-539.
Sarangthem, K., T.H.N. Singh, 2003. Efficacy of salicylic acid on growth, nitrogen metabolism and flowering of Phaseolus vulgaris. CropRes., 26: 355-360.

Singh R., Sharma R. R., Tyagi S. K. 2007. Pre-harvest foliar application of calcium and boron influences physiological disorders, fruit yield and quality of strawberry (Fragaria $\times$ ananassa Duch.). Scientia Horticulturae, 112: 215-220.

https://doi.org/10.1016/j.scienta.2006.1 2.019Thomidis T., Karagiannidis N., Stefanou S. 2017. Influence of boron applications on preharvest and postharvest nectarine fruit rot caused by brown rot. Australasian Plant Pathology, 46 (2): 177-181. https://doi.org/10.1007/s13313-0170474-3

Sugiura, T., M. Shiraishi, S. Konno and A. Sato. 2018. Prediction of skin coloration of grape berries from air temperature.

Tanaka, M., Wallace, I.S., Takano, J., Roberts, D.M., Fujiwara, T., 2008. NIP6;1 is a boric acid channel for preferential transport of boron to growing shoot tissues in Arabidopsis. Plant Cell 20, 2860-2875.

Xuan, H., Streif, J., Saquet, A., Romheld, V., Bangerth, F., 2005. Application of boron with calcium affects respiration and ATP/ADP ratio in 'Conference' pears during controlled atmosphere storage. J. Hort. Sci. Biotech. 80, 633637.

\section{How to cite this article:}

Khilari. J. M, S. D. Ramteke, Shared Bhagwat, J. N. Kalbhor, T. S. Shelake and Bhange. M. A. 2020. Effect of Foliar Application of Micronutrient on Quality and Shelf Life in Table Grapes under Tropical Conditions of India. Int.J.Curr.Microbiol.App.Sci. 9(03): 532-542. doi: https://doi.org/10.20546/ijcmas.2020.903.062 